Marko Miljković ${ }^{1}$

Biljana Jovanović Gavrilović ${ }^{2}$

Jelica Petrović Vujačić ${ }^{3}$
JEL: H54, 018

DOI: $10.5937 /$ industrija46-18043

UDC: 339.56

339.97(4-672EU)

Original Scientific Paper

\title{
The Trans-European Transport Corridors: Contribution to Economic Performances of European Regions
}

\author{
Article history: \\ Received: 30 March 2018 \\ Sent for revision: 20 April 2018 \\ Received in revised form: 25 May 2018 \\ Accepted: 25 May 2018 \\ Available online: 29 June 2018
}

\begin{abstract}
Previous empirical researches have mostly confirmed the existence of positive impact of transport infrastructure investments on economic growth of national economies. There are a very few researches carried out at the lower levels of territorial units, mostly at the levels of NUTS-1 or NUTS-2 statistical regions. The aim of this paper is to analyse economic effects of transport infrastructure development at even lower level of territorial units, i.e. at the level of NUTS-3 statistical regions. The paper compares economic performances of the TEN-T European regions characterized by developed core trans-European road and rail transport network, with economic performances of other regions without the core network. A significant difference in favour of the TEN-T regions was identified, both in the case of gross value added of the entire economy and gross value added of the manufacturing industry. No significant differences were identified in terms of the employment rate. On the other hand, the labour productivity is higher in the TEN-T regions, primarily in the manufacturing industry, as a direct consequence of reducing transport time and transport costs.
\end{abstract}

Key words: transport infrastructure, TEN-T, core network corridors, economic performances, gross value added, labour productivity, statistical NUTS-3 regions.

\footnotetext{
${ }^{1}$ University of Belgrade, Faculty of Transport and Traffic Engineering, m.miljkovic@sf.bg.ac.rs

${ }^{2}$ University of Belgrade, Faculty of Economics

${ }^{3}$ University of Belgrade, Faculty of Transport and Traffic Engineering 


\section{Transevropski saobraćajni koridori: doprinos ekonomskim performansama evropskih regiona}

Apstrakt: Dosadašnja empirijska istraživanja većinom su potvrdila postojanje pozitivnog uticaja investicija u saobraćajnu infrastrukturu na privredni rast nacionalnih privreda. Malo je istraživanja koja su sprovođena na nivou nižih teritorijalnih jedinica, pri čemu se radi o istraživanjima na nivou statističkih NUTS-1 i NUTS-2 regiona. Cilj ovog rada je da analizu o ekonomskim efektima razvoja saobraćajne infrastrukture spusti na još niži nivo teritorijalne podele, na nivo statističkih NUTS-3 regiona za koje istraživanja nisu sprovođena. U radu se porede ekonomske performanse evropskih regiona kroz koje prolaze najznačajniji transevropski drumski i železnički koridori sa performansama evropskih regiona kroz koje ovi koridori ne prolaze. Ustanovljena je značajna razlika u korist regiona kroz koje prolaze navedeni koridori, kako kada se radi o ukupnoj bruto dodatoj vrednosti, tako i kada se radi o bruto dodatoj vrednosti prerađivačke industrije. Nisu ustanovljene značajne razlike u pogledu stope zaposlenosti, ali jesu u pogledu produktivnosti rada, pre svega u prerađivačkoj industriji, što je direktna posledica smanjenja vremena transporta i transportnih troškova.

Ključne reči: saobraćajna infrastruktura, TEN-T, osnovna mreža koridora, ekonomske performanse, bruto dodata vrednost, produktivnost rada, statistički NUTS-3 regioni.

\section{Introduction}

Economic literature has devoted much attention to researching the impact of infrastructure investments on the economic growth and development of national economies over the last three decades. The first empirical research in this field was conducted by Aschauer (1989), who analysed the impact of public investments on the production of the US economy between 1949 and 1985. He concluded that public investments in highways, public passenger transport systems, airports, production, transmission, distribution and supply of electricity and gas, as well as in water and sewerage systems made a significant impact on growth of productivity in the US economy. In addition to this, his study and results decisively contributed to a consideration of causes of the slowdown in the growth of total factor productivity in the United States in the 1970s. The most frequently highlighted causes included the decline of investments in research and development, the rise in energy prices, the oil crisis and the halt in labour migration from agricultural to more productive activities. Namely, Aschauer (1989) found that the slowdown in the growth of 
total factor productivity is associated with the slowdown in the growth of total stock of public capital in the US economy.

The above mentioned results, which confirmed that public investments in infrastructure had a significant impact on total factor productivity, inspired many economists to a further research on significance and economic effects of infrastructure investments. In this paper, special attention is paid to transport infrastructure. The economic effects of investments in transport infrastructure are numerous and include a positive impact on productivity of the economy, level of employment and business activity, volume of trade and availability of goods and services, time savings and reduction of transport costs, value of assets, as well as on many other socio-economic variables. Nowadays, economic literature pays most attention to the positive contributions of transport infrastructure investments to economic growth, i.e. growth of gross domestic product in real terms.

Various channels of infrastructure investment impact on economic growth can be identified. Banister \& Berechman (2001) consider that transport infrastructure investments can lower the costs and raise competitiveness of products, which stimulates the production and contributes to economic growth, but it also opens the door to greater savings and investments. Investments in transport infrastructure also affect aggregate demand level by stimulating the construction industry, as well as a series of related branches of manufacturing industry, whose inputs are used in the construction industry (Munnell, 1992; Wang, 2002). Furthermore, investments in transport infrastructure also provide positive signals to the key sectors of the economy and create positive expectations (Fedderke \& Garlick, 2008).

Most empirical studies on relations between transport infrastructure investments and economic growth rely on the approach established by Aschauer (1991), Munnell (1992) and Holtz-Eakin \& Schwartz (1995), i.e. on the Cobb-Douglas production function. Thereby, infrastructure as a production factor is added to the existing production factors (labour and capital). The studies are carried out at the level of samples with several countries over a longer time period by applying the econometric methodology of panel data analysis. Besides the impact of transport infrastructure, researchers usually analyse the impact of other infrastructures, such as electricity infrastructure, water and sewerage networks, irrigation infrastructure etc. (Canning \& Pedroni, 2008; Egert et al., 2009; Calderon, 2009; Straub \& Terada-Hagiwara, 2011). The results of these empirical studies differ among themselves in terms of the intensity of transport infrastructure impact on economic growth, while almost all findings agree on the existence of positive impact of transport infrastructure investments on economic growth, both in developed and developing countries. 
On the other hand, some studies (Banister \& Berechman, 2001; Aschauer, 1991) emphasize that transport infrastructure investment cannot create positive impact on economic development by itself, but the presence of a list of complementary factors in the economy is quite necessary. These preconditions include the presence of developed labour market, availability of funds for investment, existence of supportive legal, organizational and institutional policies and processes and presence of any necessary complementary policy actions such as grants, tax breaks etc.

Unlike researches carried out at the level of national economies, there are a very few researches which analysed relations between transport infrastructure and economic growth at the level of regions as lower territorial units, while studies on regional competitiveness did not include the factor of infrastructure (Zarić \& Vuković, 2010). Among these researches, analyses carried out by Del Bo \& Florio (2008), Cantos et al. (2005) and Stephan (2001) stand out.

Del Bo \& Florio (2008) analysed the relation between indicators of transport infrastructure development and economic performances in 263 regions of European Union during the period 1999-2005. The indicators of transport infrastructure development included road, rail and telecommunication infrastructure, as well as soft indicators such as time-to-market and multimodal accessibility. The authors concluded that the impact of infrastructure was important for growth of regional gross domestic product in real terms. The impact of road and rail infrastructure appeared to be of less intensity as compared with the impact of soft indicators, considering already achieved high level of development of these hard infrastructures in most regions from the sample.

Cantos et al. (2005) examined the impact of transport infrastructure on economic growth of 17 Spanish regions between 1965 and 1995. They examined the impact of road, rail, airport and sea port infrastructure and identified a significant impact of road and airport infrastructure. Thereby, the impact of road infrastructure is quite more intense, having in mind that road infrastructure represents around $60 \%$ of total public capital stock invested in Spain's transport infrastructure during the observed period.

Stephan (2001) analysed the impact of road infrastructure on the production of 21 French regions between 1978 and 1992 and 11 West German states in the period from 1970 to 1995 and identified a significant impact. More importantly, he found that there was no link in the opposite direction, i.e. that the level of regional development did not affect the allocation of infrastructure investments by regions.

All regions from the above mentioned studies correspond in their size to the statistic regions of the first and the second level of the NUTS 2013 classification. The aim of this paper is to analyse economic effects of transport 
infrastructure development at even lower level of NUTS 2013 classification, i.e. at the level of NUTS-3 statistical regions. However, given that at this level of classification data on most economic and transport indicators are not available, the analysis focuses on examining the differences in economic performances between regions with developed core trans-European transport network and other regions without the core network. Thereby, the differences in economic performances are examined for the available economic indicators, such as gross value added and its structure by economic sectors, employment rate and labour productivity. Capability of regions to attract investments, create value added and provide additional employment has a strong impact on regional competitiveness which is one of the most important components of sustainable development at regional level (Nikolić et al., 2016).

\section{Development of the Trans-European Transport Network}

The policy of developing the trans-European networks in the fields of transport, energy and telecommunications has been an integral part of the European Union's policy since the last decade of the $20^{\text {th }}$ century. In addition, the Trans-European Transport Networks (TEN-T) are related to the European Union's policy towards the development of road and rail infrastructure, inland waterways, maritime routes, airports and road-rail terminals across Europe. Union guidelines for the development of the trans-European transport network define that the TEN-T includes a comprehensive network covering all European regions, and a core network that relates to routes that connect the most important points of the comprehensive network (European Parliament, 2013). The comprehensive network covers $138,072 \mathrm{~km}$ of railroads, 136,706 $\mathrm{km}$ of roads, and $23,506 \mathrm{~km}$ of inland waterways and should be implemented by 2050 , while the core network includes $50,762 \mathrm{~km}$ of railroads, $34,401 \mathrm{~km}$ of roads, and $12,880 \mathrm{~km}$ of inland waterways and should be implemented until 2030 (DG Mobility and Transport, 2017).

In addition to building the necessary infrastructure and improving the existing one, the objective of the TEN-T policy is to remove bottlenecks and eliminate technical barriers that exist between the transport networks of EU member states, as well as to strengthen the EU's social, economic and territorial cohesion and to contribute to the creation of a single European transport area. The TEN-T policy also includes the promotion and adoption of innovative digital technologies and the use of alternative energy sources in transport (DG Mobility and Transport, 2017).

Within the core network, there are nine major corridors, as follows: Atlantic, Baltic - Adriatic, Mediterranean, North Sea - Baltic, North Sea Mediterranean, Orient - East Med, Rhine - Alpine, Rhine - Danube and 
Scandinavian -Mediterranean corridor. The planned investments in these corridors in the period from 2015 to 2030 amount to euro 853.5 billion, which equals to about euro 57 billion per year (Figure 1).

Figure 1. The planned investments in the core TEN-T network by corridors in the period 2015-2030

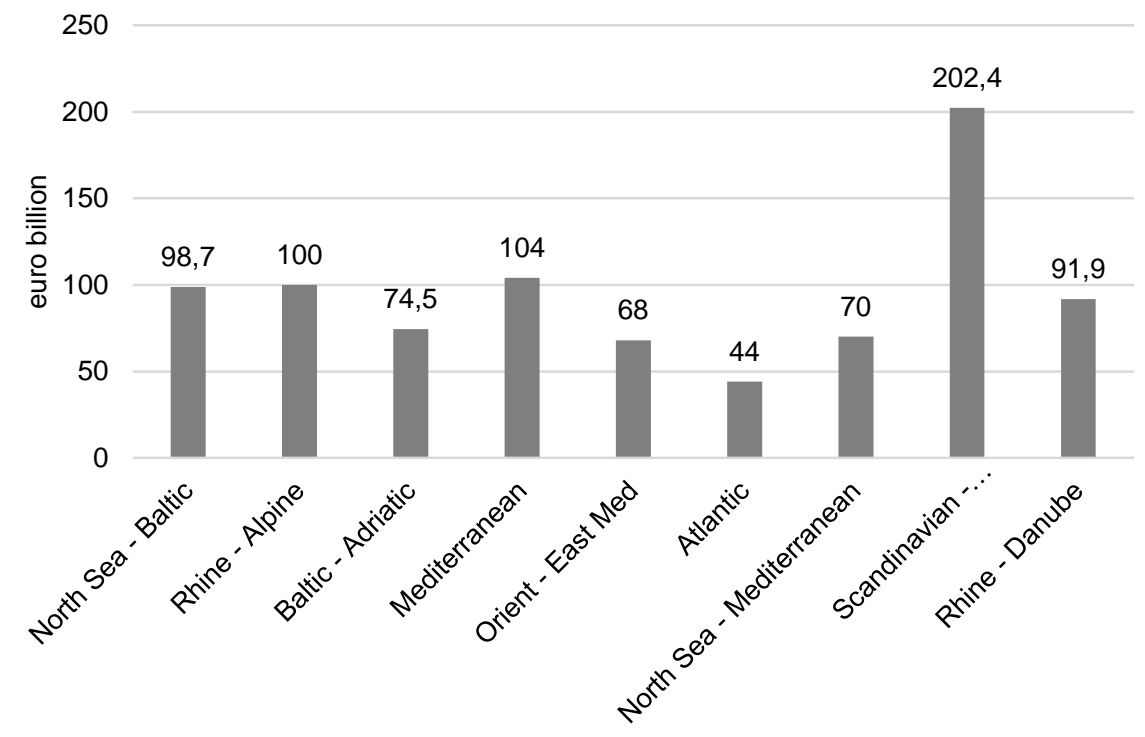

Source: DG Mobility and Transport, 2017

The estimated economic effects of these investments, apart from reducing transport time and transport costs, also include the impact on gross domestic product of European countries in the total amount of euro 6,043 billion, as well as the creation of 17.57 million job-years in the period 2015-2013 (Figure 2.).

Road infrastructure with its share of $47 \%$, as well as rail infrastructure with its share of $46 \%$, dominate in the structure of total investments in transport infrastructure of EU member states (OECD, 2018). In the period from 2015 to 2030 , more than $60 \%$ out of the total planned investments in the core TEN-T network refers to the rail infrastructure (DG Mobility and Transport, 2017). Having in mind the importance of the core network and the assessment of its wider economic effects, as well as the structure of investments by type of infrastructure, the attention of this paper is mainly paid to the impact of road and rail infrastructure on the economic performances of European regions. 
Figure 2. The estimated economic effects of investments in the core TEN-T network by corridors in the period 2015-2030

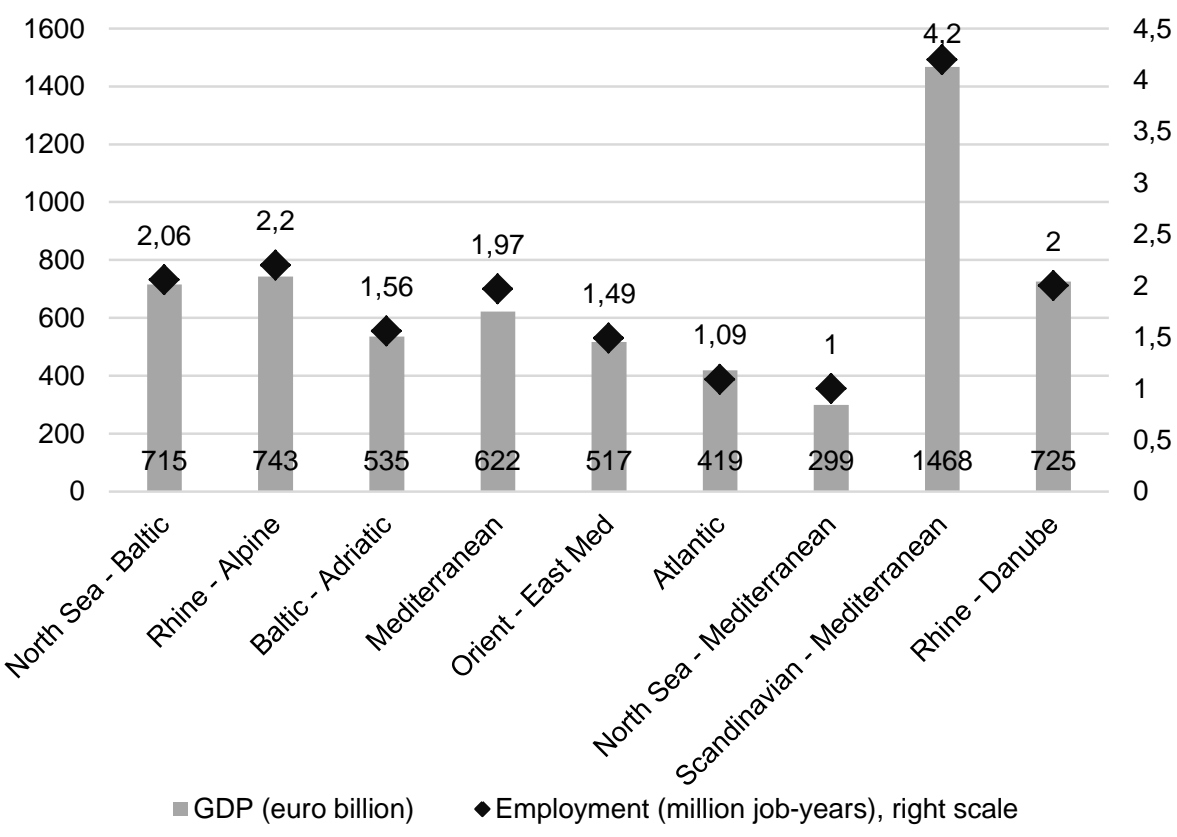

Source: DG Mobility and Transport, 2017

\section{Methodology and Data}

In accordance with the findings of other authors presented in the introductory notes, at the very beginning of this research it has been assumed that regions with developed core trans-European transport network produce higher gross value added (total and per capita), achieve higher employment rates and higher labour productivity than other regions without the core network.

The sample includes ten countries in total (Table 1). It consists of four EU member states with only one core TEN-T corridor, five EU member states with more than one core TEN-T corridor, as well as Serbia with its two corridors. In this way, the sample covered six out of nine core TEN-T corridors: the Atlantic, the Baltic-Adriatic, the Mediterranean, the North Sea - Baltic, the Orient - East Med, and the Rhine-Danube Corridor, as well as the corridors X and $\mathrm{XI}$ in Serbia. 
Miljković M., el al.: The Trans-European Transport Corridors: Contribution to Economic

Table 1. Countries in the sample and their corridors

\begin{tabular}{|l|c|}
\hline \multicolumn{1}{|c|}{ Country } & Corridors \\
\hline Bulgaria & Orient - East Med \\
\hline Spain & Atlantic and Mediterranean \\
\hline Croatia & Mediterranean \\
\hline Lithuania & North Sea - Baltic \\
\hline Poland & North Sea - Baltic and Baltic-Adriatic \\
\hline Portugal & Atlantic \\
\hline Romania & Orient - East Med and Rhine-Danube \\
\hline Slovenia & Baltic-Adriatic and Mediterranean \\
\hline Slovakia & Orient - East Med, Rhine-Danube and Baltic-Adriatic \\
\hline Serbia & Corridors X i XI \\
\hline
\end{tabular}

Source: DG Mobility and Transport 2018

The NUTS-3 statistical regions of countries from the sample are divided into groups according to whether a core TEN-T corridor (road and/or rail) passes across their territory or not. In this way, three groups of regions are formed (Table 2.):

1. Regions with developed road and rail infrastructure along core network corridors (TEN-T regions),

2. Regions with developed only road or only rail infrastructure along core network corridors (semi TEN-T regions) and

3. Regions without core network corridors (non TEN-T regions).

Table 2. Number of region in the sample, by country and category

\begin{tabular}{|l|c|c|c|c|}
\hline \multirow{2}{*}{ Country } & \multirow{2}{*}{ TEN-T regions } & \multicolumn{2}{|c|}{ Semi TEN-T regions } & \multirow{2}{*}{$\begin{array}{c}\text { Non TEN-T } \\
\text { regions }\end{array}$} \\
\cline { 3 - 4 } & & Road & Rail & 9 \\
\hline Bulgaria & 18 & 0 & 1 & 7 \\
\hline Spain & 28 & 7 & 5 & 8 \\
\hline Croatia & 6 & 6 & 1 & 2 \\
\hline Lithuania & 4 & 2 & 2 & 24 \\
\hline Poland & 43 & 5 & 0 & 9 \\
\hline Portugal & 10 & 3 & 0 & 13 \\
\hline Romania & 26 & 0 & 3 & 3 \\
\hline Slovenia & 6 & 2 & 1 & 3 \\
\hline Slovakia & 4 & 0 & 1 & 9 \\
\hline Serbia & 12 & 0 & 4 & 87 \\
\hline TOTAL & 157 & 25 & 18 & \\
\hline
\end{tabular}

Source: Authors' calculation based on Eurostat (2015) and DG Mobility and transport (2018) 
Data on gross value added by economic activities, population, and number of employees by economic activities are collected. Data for EU member states are retrieved from Eurostat Database (2018) on regional economic accounts, while data for Serbia are retrieved from Statistical Office of the Republic of Serbia Database (2018). The latest available data for all countries are for the year 2014. Gross value added is expressed at current prices. Labour productivity is estimated by gross value added per employee. Given that data on the employment rate, as well as data on the working age population at the level of NUTS-3 regions are not available, the employment rate is estimated as the ratio of employed to total population of the regions.

The hypotheses are defined in the following way:

1. Null hypothesis $H_{0}$ : $G V A_{1} \leq G V A_{2}$, against alternative hypothesis $H_{1}$ : $G V A_{1}>G V A_{2}$, where GVA $A_{1}$ represents average gross value added of the TEN-T regions, and $\mathrm{GVA}_{2}$ average gross value added of the non TEN-T regions.

2. Null hypothesis $\mathrm{H}_{0}$ : GVApc $1 \leq \mathrm{GVApc}_{2}$, against alternative hypothesis $\mathrm{GVApc}_{1}>\mathrm{GVApc}_{2}$, where GVApc ${ }_{1}$ represents average gross value added per capita of the TEN-T regions, and $\mathrm{GVApc}_{2}$ average gross value added per capita of the non TEN-T regions.

3. Null hypothesis $H_{0}$ : GVAm $\leq G \vee A m_{2}$, against alternative hypothesis $H_{1}$ : GVAm $>$ $>G V A m_{2}$, where GVAm 1 represents average gross value added of the manufacturing industry of the TEN-T regions, and $\mathrm{GVAm}_{2}$ average gross value added of the manufacturing industry of the non TEN-T regions.

4. Null hypothesis $\mathrm{H}_{0}: \quad G V A m p c_{1} \leq G V A m p c_{2}$, against alternative hypothesis $\mathrm{GVAmpc}_{1}>\mathrm{GVAmpc}_{2}$, where $\mathrm{GVAmpc}_{1}$ represents average gross value added of the manufacturing industry per capita of the TEN-T regions, and GVAmpc 2 average gross value added of the manufacturing industry per capita of the non TEN-T regions.

5. Null hypothesis $\mathrm{H}_{0}$ : $\mathrm{E}_{1} \leq \mathrm{E}_{2}$, against alternative hypothesis $\mathrm{H}_{1}$ : $\mathrm{E}_{1}>\mathrm{E}_{2}$, where $E_{1}$ represents average employment rate of the TEN-T regions, and $E_{2}$ average employment rate of the non TEN-T regions.

6. Null hypothesis $\mathrm{H}_{0}$ : $\mathrm{PROD}_{1} \leq \mathrm{PROD}_{2}$, against alternative hypothesis $\mathrm{H}_{1}$ : $\mathrm{PROD}_{1}>\mathrm{PROD}_{2}$, where $P R O D_{1}$ represents average labour productivity of the TEN-T regions, and $\mathrm{PROD}_{2}$ average labour productivity of the non TEN-T regions.

7. Null hypothesis $\mathrm{H}_{0}$ : $\mathrm{PRODm}_{1} \leq \mathrm{PRODm}_{2}$, against alternative hypothesis $\mathrm{H}_{1}$ : $\mathrm{PRODm}_{1}>\mathrm{PRODm_{2 }}$, where $\mathrm{PRODm_{1 }}$ represents average labour productivity in the manufacturing industry of the TEN$\mathrm{T}$ regions, and $\mathrm{PRODm} \mathrm{m}_{2}$ average labour productivity in the manufacturing industry of the non TEN-T regions. 
The method used to test research hypotheses is the t-test for difference between two means when population variance is unknown. This test is chosen because of its robustness with respect to departures from normality (Posten, 1984). The $t$-score $\left(t_{0}\right)$ is calculated in the following way (Petrović, 2006):

$$
t_{0}=\frac{\overline{X_{n 1}}-\overline{X_{n 2}}}{s_{n 1, n 2} * \sqrt{\frac{1}{n 1}+\frac{1}{n 2}}},
$$

Where $\overline{X_{n 1}}$ represents the average value for the TEN-T regions from the sample (i.e. GVA $1, \mathrm{GVApc}_{1}, \mathrm{GVAm}_{1}, \mathrm{GVAmpc}_{1}, \mathrm{E}_{1}, \mathrm{PROD}_{1}$ or $\mathrm{PRODm}_{1}$ depending on which hypothesis is being tested), $\overline{X_{n 2}}$ average value for the non TEN-T regions from the sample (i.e. GVA $, \mathrm{GVApc}_{2}, \mathrm{GVAm}_{2}, \mathrm{GVAmpc}_{2}$, $E_{2}, \mathrm{PROD}_{2}$ or $\mathrm{PRODm} \mathrm{m}_{2}$ depending on which hypothesis is being tested), $\mathrm{n}_{1}$ the number of the TEN-T regions in the sample, $n_{2}$ the number of the non TEN-T regions in the sample, while $s_{n 1, n 2}$ is calculated in the following way (Petrović, 2006):

$$
s_{n 1, n 2}^{2}=\frac{\left(n_{1}-1\right) * s_{n 1}^{* 2}-\overline{s_{n 2}^{* 2}}}{n_{1}+n_{2}-2},
$$

Where $\overline{s_{n 1}^{* 2}}$ represents variance estimator for the values from the TEN-T regions, and $\overline{s_{n 2}^{* 2}}$ variance estimator for the values from the non TEN-T regions.

The critical values for $t-$ test are defined by the following expression:

$$
t_{0} \geq t_{n 1+n 2-2, \alpha} .
$$

And in that case the null hypothesis should be rejected (Petrović, 2006).

\section{Results and Discussion}

By comparing the average gross value added of the 157 TEN-T regions from the sample with the average gross value added of the 87 non TEN-T regions, it can be figured out that the TEN-T regions produce even three times higher gross value added, both in the case of all activities and in the case of the manufacturing industry (Figure 3). 
Miljković M., el al.: The Trans-European Transport Corridors: Contribution to Economic

Figure 3. Average gross value added of the TEN-T and the non TEN-T regions in 2014

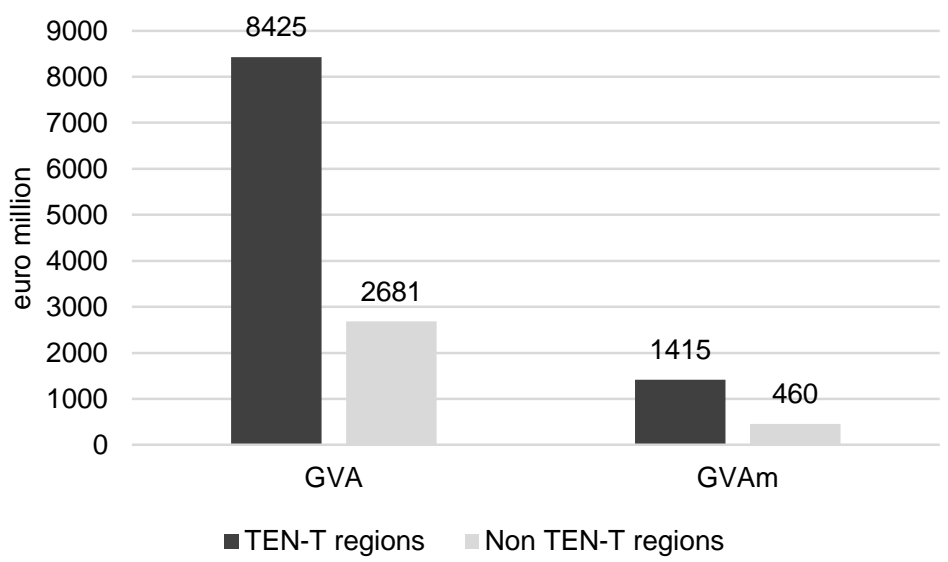

Source: Authors' calculation

By using the described methodology, based on the data from the sample, it can be concluded, at significance level of $95 \%$, that the TEN-T regions produce higher gross value added than the non TEN-T regions. This conclusion refers both to the total gross value added and to the gross added value of the manufacturing industry (Table 3 ).

Table 3. Results of the t-test on differences in gross value added

\begin{tabular}{|l|c|l|c|}
\hline Hypothesis $\mathrm{Ho}:$ & $\mathrm{GVA}_{1} \leq \mathrm{GVA}_{2}$ & Hypothesis Ho: & $\mathrm{GVAm}_{1} \leq \mathrm{GVAm}_{2}$ \\
\hline Hypothesis $\mathrm{H}_{1}:$ & $\mathrm{GVA}_{1}>\mathrm{GVA}_{2}$ & Hypothesis H1: & $\mathrm{GVAm}_{1}>\mathrm{GVAm}_{2}$ \\
\hline Value of t-score: & 3.7103 & Value of t-score: & 3.4399 \\
\hline P-value: & 0.0001 & P-value: & 0.0004 \\
\hline Conclusion: & Reject $\mathrm{H}_{0}$. & Conclusion: & Reject $\mathrm{H}_{0}$. \\
\hline
\end{tabular}

Source: Authors' calculation

Similar results are obtained when comparing gross value added per capita of the TEN-T and the non TEN-T regions. Namely, the TEN-T regions from the sample produce around $30 \%$ higher gross value added per capita as compared with the non TEN-T regions, both in the case of all activities and in the case of the manufacturing industry (Figure 4). 
Miljković M., el al.: The Trans-European Transport Corridors: Contribution to Economic

Figure 4. Gross value added per capita of the TEN-T and the non TEN-T regions in 2014

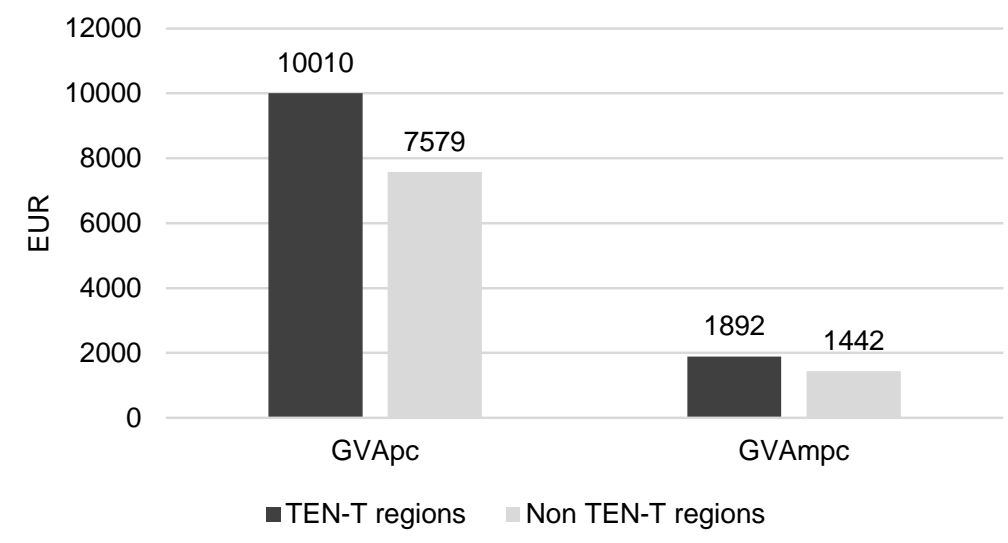

Source: Authors' calculation

By using the described methodology, based on the data from the sample, it can be concluded, at significance level of $95 \%$, that the TEN-T regions produce higher gross value added per capita than the non TEN-T regions. This conclusion refers both to the total gross value added per capita and to the gross added value per capita of the manufacturing industry (Table 4).

Table 4. Results of t-test on differences in gross value added per capita

\begin{tabular}{|l|c|l|c|}
\hline Hypothesis $\mathrm{Ho}:$ & GVApc $_{1} \leq \mathrm{GVApc}_{2}$ & Hypothesis Ho: & GVAmpc $_{1} \leq \mathrm{GVAmpc}_{2}$ \\
\hline Hypothesis $\mathrm{H}_{1}:$ & GVApc $_{1}>\mathrm{GVApc}_{2}$ & Hypothesis $\mathrm{H}_{1}:$ & $\mathrm{GVAmpc}_{1}>\mathrm{GVAmpc}_{2}$ \\
\hline Value of t-score: & 3.5047 & Value of t-score: & 2.2456 \\
\hline P-value: & 0.0003 & P-value: & 0.0132 \\
\hline Conclusion: & Reject $\mathrm{H}_{0}$. & Conclusion: & Reject $\mathrm{H}_{0}$. \\
\hline
\end{tabular}

Source: Authors' calculation

Labour productivity is considerably higher in the TEN-T regions and amounts to euro 25,775 per employee, while in the non TEN-T regions it amounts to euro 21,014 per employee. Such a difference is even more explicit in the manufacturing industry. Labour productivity in the manufacturing industry of the TEN-T regions from the sample amounts to euro 33,703 per employee, while in the non TEN-T regions it amounts to euro 24,536 per employee. On the other hand, differences in terms of employment rate are not so high. The TEN-T regions achieve employment rate of $38,59 \%$, while the non TEN-T regions achieve employment rate of $36,66 \%$ on average (Figure 5.). 
Figure 5. Employment rate and labour productivity of the TEN-T and the non TEN-T regions in 2014

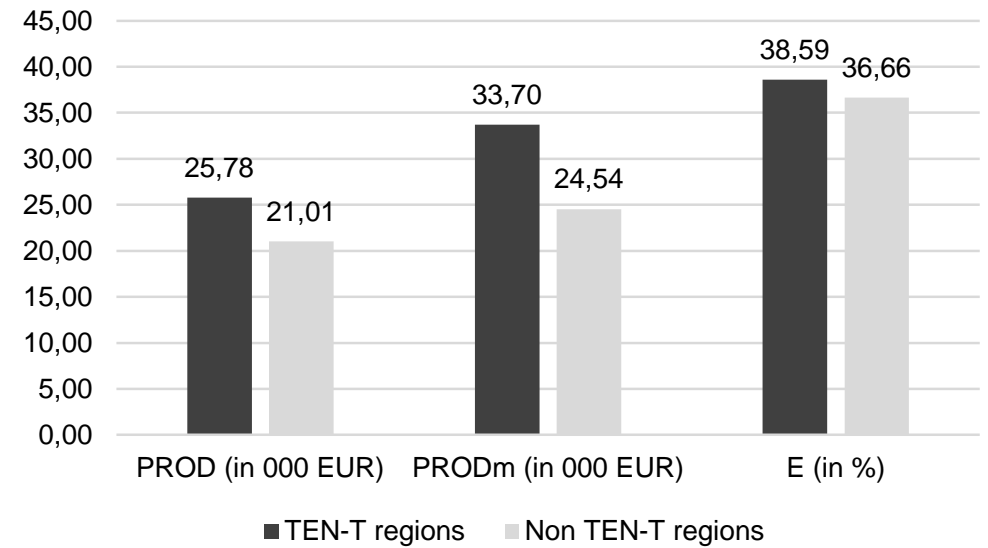

Source: Authors' calculation

Based on the t-test, it can be concluded, at significance level of $95 \%$, that the TEN-T regions are characterized by higher labour productivity than the non TEN-T regions. On the other hand, at the same significance level, it cannot be claimed that the TEN-T regions achieve a higher employment rate than the non TEN-T regions (Table 5.) Such results imply that the effects of investments in trans-European transport networks on employment level, identified by DG Mobility and Transport (2017) and Schade (2015) who assessed that one billion of transport infrastructure investment create 24 thousands job-years on average, are quite less important than the effects on productivity which are a direct consequence of reduced transport time and transport costs (Schade, 2015).

Table 5. Results of t-test on differences in productivity and employment

\begin{tabular}{|l|c|l|c|l|c|}
\hline $\begin{array}{l}\text { Hypothesis } \\
\text { Ho: }\end{array}$ & $\begin{array}{c}\mathrm{PROD}_{1} \leq \\
\mathrm{PROD}_{2}\end{array}$ & $\begin{array}{l}\text { Hypothesis } \\
\text { Ho: }\end{array}$ & $\begin{array}{c}\text { PRODm } \\
\mathrm{PRODm}_{2}\end{array}$ & $\begin{array}{l}\text { Hypothesis } \\
\text { Ho: }\end{array}$ & $\mathrm{E}_{1} \leq \mathrm{E}_{2}$ \\
\hline $\begin{array}{l}\text { Hypothesis } \\
\mathrm{H}_{1}:\end{array}$ & $\begin{array}{c}\mathrm{PROD}_{1}> \\
\mathrm{PROD}_{2}\end{array}$ & $\begin{array}{l}\text { Hypothesis } \\
\mathrm{H}_{1}:\end{array}$ & $\begin{array}{c}\text { PRODm } \\
\mathrm{PRODm}_{2}>\end{array}$ & $\begin{array}{l}\text { Hypothesis } \\
\mathrm{H}_{1}:\end{array}$ & $\mathrm{E}_{1}>\mathrm{E}_{2}$ \\
\hline $\begin{array}{l}\text { Value of t- } \\
\text { score: }\end{array}$ & 2.8639 & $\begin{array}{l}\text { Value of t- } \\
\text { score: }\end{array}$ & 3.0424 & $\begin{array}{l}\text { Value of t- } \\
\text { score: }\end{array}$ & 1.5619 \\
\hline P-value: & 0.0023 & P-value: & 0.0014 & P-value: & 0.0600 \\
\hline Conclusion: & $\begin{array}{c}\text { Reject } \\
\mathrm{H}_{0} .\end{array}$ & Conclusion: & Reject $\mathrm{H}_{0}$. & Conclusion: & $\begin{array}{l}\mathrm{H}_{0} \text { cannot } \\
\text { be rejected. }\end{array}$ \\
\hline
\end{tabular}

Source: Authors' calculation 
Miljković M., el al.: The Trans-European Transport Corridors: Contribution to Economic

\section{Conclusion}

Results presented in this paper identified the existence of significant differences in the level of gross value added and labour productivity between European regions with developed road and rail core transport network and other European regions without the core network. Particularly important contribution refers to the conclusion that development of the core TEN-T network has quite stronger impact on labour productivity through the cost reduction channel as compared with the impact on employment rate.

This research is carried out at the lowest possible level of territorial units, the NUTS-3 level, which has not been done so far. On the other hand, a disadvantage of this research can be found in the fact that at such low level of territorial units many indicators of transport infrastructure and economic development are not available. Therefore, it is not possible to conduct some more complex analysis of transport infrastructure impact on regional growth, but only to identify the existence or non-existence of differences in economic performances between regions with developed infrastructure and other regions.

\section{References}

Aschauer, D.A. (1989). Is public expenditure productive. Journal of Monetary Economics, 23(2), 177-200. doi:10.1016/0304-3932(89)90047-0

Aschauer, D.A. (1991). Transportation spending and economic growth. American Public Transit Association.

Banister, D., \& Berechman, J. (2001). Transport investment and the promotion of economic growth. Journal of Transport Geography, 9(3), 209-218. doi:10.1016/s0966-6923(01)00013-8

Calderon, C. (2009). Infrastructure and Growth in Africa. World Bank, Working Paper Series, doi:10.1596/1813-9450-4914

Canning, D., \& Pedroni, P. (2008). Infrastructure, Long-Run Economic Growth and Causality Tests for Cointegrated Panels. Manchester School, 76(5), 504-527. doi:10.1111/j.1467-9957.2008.01073.x

Cantos, P., Gumbau-Albert, M., \& Maudos, J. (2005). Transport infrastructures, spillover effects and regional growth: evidence of the Spanish case. Transport Reviews, 25(1), 25-50. doi:10.1080/014416410001676852

Del Bo, C., \& Florio, M. (2008). Infrastructure and growth in the European Union: an empirical analysis at the regional level in a spatial framework. Department of Economics, Management and Quantitative Methods at Università degli Studi di Milano. Departmental Working Papers, No. 2008-37.

-DG Mobility and Transport. (2017). Delivering TEN-T, Facts and Figures.

-DG Mobility and Transport, (2018). TENtec Interactive Map Viewer. Retrieved from http://ec.europa.eu/transport/infrastructure/tentec/tentec-portal/map/maps.html 
Miljković M., el al.: The Trans-European Transport Corridors: Contribution to Economic

Egert, B., Kozluk, T., \& Sutherland, D. (2009). Infrastructure and growth: Empirical Evidence. OECD Economics Department Working Papers, No. 685.

-European Parliament. (2013). Union guidelines for the development of the transEuropean transport network. Regulation (EU) No 1315.

-Eurostat. (2015). Regions in the European Union - Nomenclature of territorial units for statistics - NUTS. 2013/EU-28.

-Eurostat. (2018). Database. http://ec.europa.eu/eurostat/data/database.

Fedderke, J., \& Garlick, R. (2008). Infrastructure development and economic growth in South Africa: a review of the accumulated evidence. Policy Paper, No 12, School of Economics, University of Cape Town.

Holtz-Eakin, D., \& Schwartz, A.E. (1995). Infrastructure in a structural model of economic growth. Regional Science and Urban Economics, 25(2), 131-151. doi:10.1016/0166-0462(94)02080-z

Munnell, A.H. (1992). Policy Watch: Infrastructure Investment and Economic Growth. Journal of Economic Perspectives, 6(4), 189-198. doi:10.1257/jep.6.4.189

Nikolić, M., Filipović, M., \& Pokrajac, S. (2016). Regional Competitiveness for Achieving Sustainable Development - The Case of Serbia. Industrija, 44(3), 726. doi:10.5937/industrija44-10615

-OECD. (2018). Transport Infrastructure Investment Database. https://data.oecd.org/transport/infrastructure-investment.htm.

Petrović, (. (2006). Teorijska statistika - Teorija statističkog zaključivanja. Beograd: Ekonomski fakultet - Centar za izdavačku delatnost.

Posten, H.O. (1984). Robustness of Statistical Methods and Nonparametric Statistics. Theory and Decision Library (Series B: Mathematical and Statistical Methods). Dordrecht: Springer. doi:10.1007/978-94-009-6528-7

Schade, W., Krail, M., Hartwig, J., Walther, C., Sutter, D., Killer, M., . . . Hitscherich, K. (2015). Cost of non-completion of the TEN-t. Fraunhofer Institut für System und Innovationsforschung (ISI).

-Statistical Office of the Republic of Serbia Database. (2018). http://data.stat.gov.rs/?caller=SDDB\&languageCode=en-US.

Stephan, A. (2001). Regional infrastructure policy and its impact on productivity: A comparison of Germany and France. Discussion Paper. Berlin: Wissenschaftszentrum. FS IV 01-02.

Straub, S., \& Terada-Hagiwara, A. (2011). Infrastructure and Growth in Developing Asia. Asian Development Review, 28 (1), pp. 119-156.

Zarić, S., \& Vuković, D. (2010). Regional Competitiveness as a Deciding Factor for Investors. In Proceedings of Scientific Meeting "Institutional Changes as a Determinant of Economic Development of Serbia in 2010". University of Kragujevac - Faculty of Economics.

Wang, E.C. (2002). Public infrastructure and economic growth: a new approach applied to East Asian economies. Journal of Policy Modeling, 24(5), 411-435. doi:10.1016/s0161-8938(02)00123-0 